I. L. Shynkovenko ${ }^{1}$, T. V. Ilyina ${ }^{1}$, O. V. Goryacha ${ }^{1}$, A. M. Kovalyova ${ }^{1}$, T. P. Osolodchenko ${ }^{2}$, A. M. Komisarenko ${ }^{1}$

${ }^{1}$ National University of Pharmacy

${ }^{2}$ Mechnikov Institute of Microbiology and Immunology of NAMS of Ukraine

\title{
The phytochemical profile and antibacterial activity of fluid extracts of Galium verum L. herb
}

Aim. To obtain and study the qualitative composition and the content of the main groups of biologically active substances (BAS) of fluid extracts (FEs) of Galium verum L. herb and to assess their antibacterial activity.

Materials and methods. FEs of Galium verum L. herb were obtained by three-fold water extraction or ethanol ( $20 \%, 60 \%, 96 \%$ ) extraction of the raw material when heating, followed by the concentration of the combined extracts. Phenolic compounds of FEs were studied by the methods of paper and thin-layer chromatography, and spectrophotometry. The content of polysaccharides was determined gravimetrically. The antibacterial activity of FEs was determined in vitro by the agar diffusion method.

Results and discussion. The chromatographic study of FEs of Galium verum L. herb revealed the presence of chlorogenic acid and rutin in all FEs, the fluid $96 \%$ ethanol extract contains chlorogenic acid, cyanoside, quercetin and rutin. Hydroxycinnamic acids, flavonoids and the amount of phenolic compounds were quantified in all extracts, and polysaccharides were determined in the aqueous extract and $20 \%$ ethanol extract. When studying the antimicrobial activity of FEs it has been found that the fluid $96 \%$ ethanol extract exhibits the highest activity. Bacillus subtilis was the most susceptible to all the extracts under study. Proteus vulgaris showed insignificant sensitivity to the test concentration of fluid extracts obtained with water and $60 \%$ ethanol. The rest of the microorganism test strains used were sufficiently sensitive to the FEs under study.

Conclusions. The results obtained indicate the prospects of further in-depth study of the antimicrobial activity of fluid extracts of Galium verum L. herb in order to develop antibacterial agents on their basis.

Key words: Galium verum L.; fluid extracts; antibacterial activity

І. Л. Шинковенко, Т. В. Ільїна, О. В. Горяча, А. М. Ковальова, Т. П. Осолодченко, А. М. Комісаренко

Дослідження рідких екстрактів 3 трави підмаренника справжнього (Galium verum L.) та їх антибактеріальної активності

Мета роботи - одержання, дослідження якісного складу та вмісту основних груп біологічно активних речовин (БАР) екстрактів рідких (ЕР) трави підмаренника справжнього і вивчення їх антибактеріальної активності.

Матеріали та методи. ЕР трави підмаренника справжнього отримані шляхом триразової екстракції сировини водою або 20 \%, 60 \%, 96 \% етанолом при нагріванні з подальшим концентруванням об'єднаних витяжок. Фенольні сполуки ЕР досліджували методами паперової та тонкошарової хроматографії і спектрофотометрії. Вміст полісахаридів визначали гравіметричним методом. Антибактеріальну активність ЕР встановлювали методом «колодязів» in vitro.

Результати та їх обговорення. При хроматографрічному дослідженні ЕР трави підмаренника справжнього встановлено, що в усіх ЕР міститься хлорогенова кислота та рутин; ЕР з використанням як екстрагенту 96 \% етанолу містить хлорогенову кислоту, цинарозид, кверцетин і рутин. Визначено вміст гідроксикоричних кислот, фрлавоноїдів та суми фенольних сполук в усіх екстрактах, вміст полісахаридів - у водному та спиртовому (20 \%) екстрактах. При дослідженні антимікробної активності РЕ встановлено, що найбільшу активність проявляє екстракт, одержаний з використанням 96 \% етанолу. Найбільш чутливим до всіх досліджуваних екстрактів виявився Bacillus subtilis. Незначну чутливість до випробовуваної концентрації EP, отриманих за допомогою води та 60 \% етанолу, показав Proteus vulgaris. Решта використаних тест-штамів мікроорганізмів виявилась достатньо чутливою до досліджуваних ЕР.

Висновки. Отримані результати свідчать про перспективність подальшого поглибленого дослідження антимікробної активності ЕР з трави підмаренника справжнього з метою створення на їх основі антибактеріальних засобів.

Ключові слова: підмаренник справжній; екстракти рідкі; антибактеріальна активність

И. Л. Шинковенко, Т. В. Ильина, О.В.Горячая, А. М. Ковалева, Т. П. Осолодченко, А. Н. Комиссаренко

Исследование жидких экстрактов из травы подмаренника настоящего (Galium verum L.) и их антибактериальной активности

Цель работы - получение, исследование качественного состава и содержания основных групп биологически активных соединений (БАС) экстрактов жидких (ЭЖ) травы подмаренника настоящего и изучение их антибактериальной активности. 
Материалы и методы. ЭЖ травы подмаренника настоящего полученны путем трехкратной экстракции сырья водой или 20 \%, 60 \%, 96 \% этанолом при нагревании с последующим концентрированием объединенных извлечений. Фенольные соединения ЭЖ исследовали методами бумажной и тонкослойной хроматографии и спектрофотометрии. Содержание полисахаридов определяли гравиметрическим методом. Антибактериальную активность ЭЖ устанавливали методом «колодцев» in vitro.

Результаты и их обсуждение. При хроматографическом изучении ЭЖ травы подмаренника настоящего установлено, что все ЭЖ содержат хлорогеновую кислоту и рутин, ЭЖ с использованием в качестве экстрагента 96 \% этанола содержит хлорогеновую кислоту, цинарозид, кверцетин и рутин. Установлено содержание гидроксикоричных кислот, фрлавоноидов и суммы фенольных соединений во всех экстрактах, содержание полисахаридов - в водном и спиртовом (20 \% этанол) экстрактах. При изучении антимикробной активности ЭЖ установлено, что наиболее активным является экстракт, полученный с использованием 96 \% этанола. Наиболее чувствительным ко всем исследованным экстрактам оказался Bacillus subtilis. Незначительную чувствительность к испытуемой концентрации ЭЖ, полученных с использованием воды и 60 \% этанола, показал Proteus vulgaris. Остальные использованные тест-штаммы микроорганизмов оказались достаточно чувствительными к исследованным ЭЖ.

Выводы. Полученные результаты свидетельствуют о перспективности дальнейшего углубленного изучения антимикробной активности жидких экстрактов из травы подмаренника настоящего с целью создания на их основе антибактериальных средств.

Ключевые слова: подмаренник настоящий; экстракты жидкие; антибактериальная активность

The search for the antibacterial and antifungal agents of the plant origin is among the topical issues facing pharmacy.

In the folk medicine Bedstraw species (Galium L.) of Madder family (Rubiaceae Juss.) are widely used in the treatment of skin diseases, respiratory and urogenital disorders, and sepsis [1]. The numerous experimental studies conducted worldwide demonstrate the antimicrobial properties of Galium species [2-5].

Previously, the antimicrobial and antifungal properties of certain Galium species were found [6]. Among them Galium verum L. should be mentioned, its lipophilic fractions exhibit a wide range of the antimicrobial and antifungal activity [7-9].

The aim of this work was to study the composition and antibacterial activity of fluid extracts of Galium verum L. herb obtained with different extragents, namely water, $96 \%$ ethanol and water-alcoholic mixtures.

\section{Materials and methods}

Galium verum herb was harvested at full flowering stage in the Kharkiv region in June of 2016.

The objects of the research were FEs of Galium verum L. herb obtained with water (EP-w) or $20 \%$ (EP-20), $60 \%$ (EP-60), $96 \%$ ethanol (EP-96) three-fold extraction (30 min each) of the air-dried raw material in the ratio of the raw material: extragent of $1: 10$ when heating with the subsequent concentration of the combined three extracts to the ratio of the raw material - finished product of $1: 10$.

Phenolic compounds of FEs were studied by paper chromatography (PC) and thin-layer chromatography (TLC). The conditions for PC were as follows: Filtrac chromatographic paper (FN-12); the solvent system of ethyl acetate - formic acid - water $(10: 2: 3, \mathrm{v} / \mathrm{v} / \mathrm{v})$; the temperature $-20{ }^{\circ} \mathrm{C}$; UV light $(\lambda=354 \mathrm{~nm})$; developers ammonia vapors; $3 \% \mathrm{KOH}$ alcohol solution. The conditions for TLC were as follows: Sorbfil and Silufol plates; UFS-254/365 irradiator; the solvent system of ethyl acetate - formic acid - water $(10: 2: 3, \mathrm{v} / \mathrm{v} / \mathrm{v})$; developers $-5 \% \mathrm{AlCl}_{3}$ alcohol solution, $3 \% \mathrm{KOH}$ alcohol solution; $2 \% \mathrm{ZrOCl}_{2}$ alcohol solution with citric acid.
As reference standards $0.1 \%$ solutions of authentic samples of chlorogenic acid, rutin, quercetin, kaempferol, apigenin, luteolin, cyanoside were used. Compounds were identified by coloring after the reaction with chromogenic developers, by the character of fluorescence in UV light and the $R_{f}$ value compared to the authentic samples.

In the fluid extracts the content of phenolic compounds was determined using an Evolution $60 \mathrm{~S}$ UV-Visible (Thermo scientific) spectrophotometer: hydroxycinnamic acids at the wavelength $\lambda=327 \mathrm{~nm}$ (as chlorogenic acid), flavonoids at the wavelength $\lambda=410 \mathrm{~nm}$ (as rutin), the amount of polyphenolic compounds at the wavelength $\lambda=270 \mathrm{~nm}$ (as gallic acid).

According to the WHO recommendations for the study of the antibacterial activity of drug products to assess the antibacterial activity of FEs the test-strains of Staphylococcus aureus ATCC 25923, Escherichia coli ATCC 25922, Pseudomonas aeruginosa ATCC 27853, Proteus vulgaris ATCC 4636, Bacillus subtilis ATCC 6633, Candida albicans 885-663 were used.

In the study $0.3 \mathrm{ml}$ of FEs were used.

The antibacterial activity of FEs was studied in vitro by the agar diffusion method (agar well method) [10]. The microbial load was $10^{7}$ microbial cells per $1 \mathrm{ml}$ of the medium; it was determined visually according to McFarland turbidity standard.

To determine the antimicrobial activity the microorganism cultures were grown on meat-peptone agar at $\mathrm{t}=37^{\circ} \mathrm{C}$. Microorganisms were cultured for 24 hours. To determine the antifungal activity of FEs the Sabouraud medium was used. The degree of sensitivity of microorganisms in relation to the FEs under study was estimated by the size of their growth inhibition zones.

The sensitivity of microorganisms to the FEs under study was measured as a radius of the inhibition zone.

The assessment of the sensitivity of microorganisms was performed according to the following criteria:

- no growth inhibition zones, as well as the inhibition zone to $10 \mathrm{~mm}$ showed that the microorganism was not sensitive to the substance studied or the selected concentration of the substance; 
The composition of fluid extracts of Galium verum L. herb

\begin{tabular}{|l|c|c|c|c|}
\hline \multirow{2}{*}{ Extragent } & \multicolumn{3}{|c|}{ The content of BAS, \% } \\
\cline { 2 - 5 } & Polysaccharides & Hydroxycinnamic acids & Flavonoids & $\begin{array}{c}\text { The amount of } \\
\text { phenolic compounds }\end{array}$ \\
\hline Water & 6.27 & 4.24 & 0.40 & 3.66 \\
\hline Ethanol 20\% & 2.40 & 3.10 & 0.24 & 2.90 \\
\hline Ethanol 60\% & $--^{*}$ & 4.13 & 0.16 & 3.84 \\
\hline Ethanol 96\% & $--^{*}$ & 2.70 & 0.18 & 2.70 \\
\hline
\end{tabular}

Note. ${ }^{*}$ - no polysaccharides.

The antimicrobial activity of extracts of Galium verum L. herb

\begin{tabular}{|l|c|c|c|c|c|c|}
\hline \multirow{2}{*}{ Extragent } & \multicolumn{6}{|c|}{ Diameter of the growth inhibition zones (mm) $(\mathrm{M}+\mathrm{m}), \mathrm{p} \leq 0.05$} \\
\cline { 2 - 7 } & $\begin{array}{c}\text { Staphylococcus } \\
\text { aureus }\end{array}$ & Escherichia coli & $\begin{array}{c}\text { Pseudomonas } \\
\text { aeruginosa }\end{array}$ & $\begin{array}{c}\text { Bacillus } \\
\text { subtilis }\end{array}$ & $\begin{array}{c}\text { Proteus } \\
\text { vulgaris }\end{array}$ & $\begin{array}{c}\text { Candida } \\
\text { albicans }\end{array}$ \\
\hline Water & $17.7 \pm 0.4$ & $17.3 \pm 0.3$ & $16.3 \pm 0.3$ & $18.7 \pm 0.3$ & $15.0 \pm 0.2$ & $15.6 \pm 0.2$ \\
\hline Ethanol 20\% & $20.0 \pm 0.2$ & $19.7 \pm 0.2$ & $15.7 \pm 0.4$ & $18.3 \pm 0.2$ & $15.3 \pm 0.3$ & $16.7 \pm 0.3$ \\
\hline Ethanol 60\% & $18.3 \pm 0.3$ & $17.3 \pm 0.3$ & $17.3 \pm 0.3$ & $21.0 \pm 0.2$ & $14.3 \pm 0.3$ & $16.4 \pm 0.3$ \\
\hline Ethanol 96\% & $20.7 \pm 0.4$ & $20.3 \pm 0.3$ & $18.7 \pm 0.4$ & $21.7 \pm 0.3$ & $18.7 \pm 0.3$ & $19.3 \pm 0.4$ \\
\hline
\end{tabular}

- inhibition zones with the diameter of $10-15 \mathrm{~mm}$ in dicated low a sensitivity of the microorganism to the concentration of the test substance;

- inhibition zones with the diameter of 15-25 mm were regarded as an indicator of sufficient sensitivity of the microorganism to the test substance;

- inhibition zones with the diameter exceeding $25 \mathrm{~mm}$ showed a high sensitivity of microorganisms to the substances studied.

The statistical processing of the results was performed according to Glants S. [11].

\section{Results and discussion}

The chromatographic study of FEs of Galium verum L. herb revealed the presence of chlorogenic acid and rutin in all FEs, the fluid $96 \%$ ethanol extract contained chlorogenic acid, cyanoside, quercetin and rutin.

The results of the BAS content determination showed that the highest quantity of polysaccharides, hydroxycinnamic acids and flavonoids was in the aqueous extract - FE-w (Tab. 1). The lowest quantity of phenolic compounds was in FE-96.

When studying the antimicrobial activity of FEs it was found that all extracts under study exhibited the antimicrobial activity (Tab. 2).

Proteus vulgaris was highly susceptible to FE-96 and unsusceptible to FE-60.
Extracts FE-20 and FE-96 exhibited the highest activity in relation to Staphylococcus aureus and Escherichia coli.

FE-96 exhibited the highest activity in relation to Proteus vulgaris, Pseudomonas aeruginosa and Candida albicans.

Bacillus subtilis was highly susceptible to FE-96 and FE-60.

On average, FE-96 exhibited the highest antimicrobial activity. Among the test strains used Bacillus subtilis was the most susceptible to all extracts under study.

\section{CONCLUSIONS}

1. For the first time the antibacterial and antifungal activities of fluid extracts of Galium verum L. herb obtained with water and ethanol (20\%,60\% and $96 \%)$ extraction and differed in the content of BAS have been studied.

2. It has been found that all fluid extracts exhibit the antimicrobial activity. The fluid $96 \%$ ethanol extract exhibits the highest activity. Bacillus subtilis was the most susceptible to all the extracts under study.

3 . The results obtained indicate the prospects of further in-depth study of the antimicrobial activity of fluid extracts of Galium verum L. herb in order to develop antibacterial agents on their basis.

Conflict of Interests: authors have no conflict of interests to declare.

\section{REFERENCES}

1. Растительные ресурсы СССР : Цветковые растения, их химический состав, использование; Семейства Caprifoliaceae - Plantaginaceae / отв. ред. П. Д. Соколов. - Л. : Наука, 1990. - 328 с.

2. Antimicrobial activities of Galium species / F. Ergun, D. Deliorman, A. Veliolgu et al. // J. Fac. Pharm. Gazi. - 1999. - Vol. 16, Issue 2. - P. 7-11.

3. Antimicrobial, anti-inflammatory, antiparasitic, and cytotoxic activities of Galium mexicanum / P. Bolivar, C. Cruz-Paredes, L. R. Hernández et al. // J. of Ethnopharmacol. - 2011. - Vol. 137, Issue 1. - P. 141-147. doi: 10.1016/j.jep.2011.04.069

4. In vitro antifungal and antibacterial activities of extracts of Galium tricornutum subsp. longipedunculatum / A. Kh. Jan, M. R. Shah, I. Anis, I. K. Marwat // J. of Enzyme Inhibition and Med. Chem. - 2008. - Vol. 24, Issue 1. - P. 192-196. doi: 10.1080/14756360802051255 
5. Comparative study of polyphenolic content, antioxidant and antimicrobial activity of four Galium species (Rubiaceae) / L. Vlase, A. Mocan, D. Hanganu et al. // Digest J. of Nanomaterials and Biostructures. - 2014. - Vol. 9, Issue 3. - P. 1085 - 1094.

6. Antimicrobial Activity of the Genus Galium L. / T. V. Ilyina, O. V. Goryacha, E. L. Toryanik et al. // Pharmacognosy Communications. 2016. - Vol. 6, Issue 1. - P. 42-47. doi: 10.5530/pc.2016.1.8

7. Дослідження впливу ліпофільних фракцій підмаренника справжнього на протилізоцимні властивості мікроорганізмів / Н. В. Кашпур, О. В. Горяча, А. Ю. Волянський та ін. // Клін. фармація. - 2011. - № 1. - С. 43-45.

8. Дослідження впливу ліпофільних фракцій трави підмаренника справжнього на адгезивні властивості мікроорганізмів / О. В. Горяча, Н. В. Кашпур, А. Ю. Волянський та ін. // Укр. журн. клін. та лабораторної медицини. - 2011. - Т. 6, № 1. - С. 78-82.

9. Протигрибкова активність ліпофільних фракцій рослин роду Galium. Повідомлення 1 / Н. В. Кашпур, О. В. Горяча, Т. В. Ільїна та ін. // Клін. фармація. - 2011. - Т. 15, № 4. - С. 50-53.

10. Решедько, Г. К. Особенности определения чувствительности микроорганизмов диско-диффузным методом / Г. К. Решедько, О. У. Стецюк // Клин. микробиол. и антимикробная химиотерапия. - 2001. - Т. 3, № 4. - С. 348-355.

11. Гланц, С. Медико-биологическая статистика / С. Гланц. - М. : Практика, 2001. - 459 с.

\section{REFERENCES}

1. Sokolov, P. D. (1990). Rastitelnye resursy SSSR: Tcvetkovye rasteniia. ikh khimicheskii sostav, ispolzovanie; Semeistva Caprifoliaceae Plantaginaceae. L.: Nauka, 328.

2. Ergun, F., Deliorman, D., Veliolgu, A., Johannson, C. B. (1999). Antimicrobial activities of Galium species. J. Fac. Pharm. Gazi, 16 (2), $7-11$.

3. Bolivar, P., Cruz-Paredes, C., Hernández, L. R., Juárez, Z. N., Sánchez-Arreola, E., Av-Gay, Y., Bach, H. (2011). Antimicrobial, anti-inflammatory, antiparasitic, and cytotoxic activities of Galium mexicanum. Journal of Ethnopharmacology, 137 (1), $141-147$. doi: 10.1016/j.jep.2011.04.069

4. Jan, A. K., Shah, M. R., Anis, I., Marwat, I. K. (2008). In vitroantifungal and antibacterial activities of extracts of Galium tricornutum subsp.longipedunculatum. Journal of Enzyme Inhibition and Medicinal Chemistry, 24 (1), 192-196. doi: 10.1080/14756360802051255

5. Vlase, L., Mocan, A., Hanganu, D., Benedec, D., Gheldiu, A., Crișan, G. (2014). Comparative study of polyphenolic content, antioxidant and antimicrobial activity of four Galium species (Rubiaceae). Digest Journal of Nanomaterials and Biostructures, 9 (3), 1085 - 1094.

6. Tatyana Vasilevna, I., Olga Volodymyrivna, G., Erica Leonidivna, T., Irina Aleksandrovna, K., Alla Mihaylovna, K. (2016). Antimicrobial Activity of the Genus Galium L. Pharmacognosy Communications, 6 (1), 42-47. doi: 10.5530/pc.2016.1.8

7. Kashpur, N. V., Horiacha, O. V., Volianskyi, A. Yu. et al. (2011) Klinichna farmatsiia-Clinical Pharmacy, 1, $43-45$.

8. Horiacha, O. V., Kashpur, N. V., Volianskyi, A. Yu. et al. (2011). Ukrainskyi zhurnal klinichnoi ta laboratornoi medytsyny, 6 (1), $78-82$.

9. Kashpur, N. V., Horiacha, O. V., Ilina, T. V. et al. (2011). Klinichna farmatsiia-Clinical Pharmacy, 15 (4), 50-53.

10. Reshedko, G. K., Stetciuk, O. U. (2001). Klinicheskaia mikrobiologiia i antimikrobnaia khimioterapiia, 3 (4), $348-355$.

11. Glantc, S. (2001). Mediko-biologicheskaia statistika. M.: Praktika, 459.

Information on authors:

Shynkovenko I. L., postgraduate student of the Pharmacognosy Department, National University of Pharmacy.

Ilyina T. V., Doctor of Pharmacy (Dr. habil.), associate professor, professor of the Pharmacognosy Department, National University of Pharmacy.

E-mail: ilyinatany86@gmail.com. ORCID: http://orcid.org/0000-0003-3728-9752

Goryacha O. V. Candidate of Pharmacy (Ph.D.), teaching assistant of the Pharmacognosy Department, National University of Pharmacy.

ORCID - https://orcid.org/0000-0001-9877-7392

Kovalyova A. M., Doctor of Pharmacy (Dr. habil.), professor of the Pharmacognosy Department, National University of Pharmacy. E-mail: allapharm@yahoo.com. ORCID - http://orcid.org/0000-0002-1758-1222

Osolodchenko T. P., Candidate of Biology (Ph.D.), senior researcher, head of the Laboratory of Biochemistry and Biotechnology, Mechnikov Institute of

Microbiology and Immunology of the NAMS of Ukraine. E-mail: imitatyana@mail.ru

Komissarenko A. M., Doctor of Pharmacy (Dr. habil.), professor of the Chemistry of Natural Compounds Department, National University of Pharmacy.

Інформація про авторів:

Шинковенко І. Л., аспірант кафедри фармакогнозії, Національний фармацевтичний університет.

Ільїна Т. В., д-р фарм. наук, професор кафедри фармакогнозії, Національний фармацевтичний університет. E-mail: ilyinatany86@gmail.com.

ORCID: http://orcid.org/0000-0003-3728-9752

Горяча О. В., канд. фарм. наук, асистент кафедри фармакогнозії, Національний фармацевтичний університет. ORCID - https://orcid.org/0000-0001-9877-7392

Ковальова А. М., д-р фарм. наук, професор кафедри фармакогнозії, Національний фармацевтичний університет. E-mail: allapharm@уаһоo.com.

ORCID - http://orcid.org/0000-0002-1758-1222

Осолодченко Т. П., канд. біол. наук, старший науковий співробітник, завідувач лабораторії біохімії та біотехнології, Державна установа «Інститут мікробіології та імунології імені I. І. Мечникова НАМН України». E-mail: imitatyana@mail.ru

Комісаренко А. М., д-р фарм. наук, професор кафедри хімії природних сполук, Національний фармацевтичний університет.

Информация об авторах:

Шинковенко И. Л., аспирант кафедры фармакогнозии, Национальный фармацевтический университет.

Ильина Т. В., д-р фарм. наук, профессор кафедры фармакогнозии, Национальный фармацевтический университет. Е-mail: ilyinatany86@gmail.com.

ORCID - http://orcid.org/0000-0003-3728-9752

Горячая О. В., канд. фарм. наук, ассистент кафедры фармакогнозии, Национальный фармацевтический университет. ORCID - https://orcid.org/0000-0001-9877-7392

Ковалева А. М., д-р фарм. наук, профессор кафедры фармакогнозии, Национальный фармацевтический университет. E-таil: allapharm@уаһоо.сот.

ORCID - http://orcid.org/0000-0002-1758-1222

Осолодченко Т. П., канд. биол. наук, старший научный сотрудник, зав. лабораторией биохимии и биотехнологии, Государственное учреждение «Институт микробиологии и иммунологии имени И. И. Мечникова НАМН Украины». E-mail: imitatyana@mail.ru

Комиссаренко А. Н., д-р фарм. наук, профессор кафедры химии природных соединений, Национальный фармацевтический университет. 